\title{
37. THE EVOLUTION OF THE GLOBOROTALIA TRUNCATULINOIDES AND GLOBOROTALIA CRASSAFORMIS GROUP IN THE PLIOCENE AND PLEISTOCENE OF THE TIMOR TROUGH, DSDP LEG 27, SITE 262
}

\author{
Fred Rögl, Geology Department, Swiss Federal Institute of Technology, Zurich, Switzerland
}

\begin{abstract}
Site 262 in the Timor Trough penetrated 442 meters of Recent, Pleistocene, and Pliocene sediments below a water depth of 2298 meters. Core $1(0-5 \mathrm{~m})$ is Recent. The Pleistocene measures 332.5 meters (Cores 2-36). It is characterized by uniform sedimentation and rich calcareous and siliceous plankton. A gradual shallowing of the Timor Trough begins within the upper Pliocene (Core 40), reaching shallow-water conditions Core 45 (?middle-lower Pliocene boundary). The section was subdivided following the planktonic foraminiferal zonal scheme of Bolli and Premoli Silva (1973). Because of the great thickness of the upper Pliocene-Pleistocene, Site 262 proved suitable for the investigation of evolutionary trends in the Globorotalia crassaformis-tosaensis-truncatulinoides groups.

Globorotalia tosaensis tenuitheca and G. tosaensis tosaensis derived in the lower to middle Pliocene from $G$. crassaformis crassaformis. Somewhat later the thick-walled $G$. cf. tosaensis also evolved. All these taxa range into the lower Pleistocene. Branching off from Globorotalia tosaensis tenuitheca, with transitional stages in Cores 39-37, Globorotalia truncatulinoides truncatulinoides becomes fully developed in Core 36. The Pliocene-Pleistocene boundary is marked by the appearance of typical Globorotalia truncatulinoides. The thickwalled Globorotalia truncatulinoides pachytheca evolved from $G$. truncatulinoides truncatulinoides. The Globorotalia crassaformis subspecies crassaformis, oceanica, and ronda are distinguished in the Pliocene. Globorotalia crassaformis hessi, G. crassaformis cf. viola, and $G$. aff. crotonensis split off from this group within the lower to middle Pleistocene. Notable are the synchronized coiling changes of all these subspecies of $G$. crassaformis; of special interest is the one from left to right in Core 7 in the upper Pleistocene.
\end{abstract}

\section{INTRODUCTION}

The great thickness of Pliocene-Pleistocene sediments at Site 262 in the Timor Trough combined with a wellpreserved rich planktonic foraminiferal fauna, makes the section ideally suited for evolutionary studies in the Globorotalia crassaformis-tosaensis-truncatulinoides groups.

The significance of Globorotalia truncatulinoides truncatulinoides as a marker for the Pliocene-Pleistocene boundary is well known. This boundary was based by Ericson et al. (1964) in deep-sea cores of the Atlantic on the first appearance of this taxon, together with the extinction of Discoasteridae and some other changes in the planktonic foraminiferal association. Banner and Blow $(1965,1967)$ also characterized the base of the Pleistocene and the Zone N22, in correlation with the type area of the Calabrian, by the first appearance of $G$. truncatulinoides. The occurrence of $G$. truncatulinoides and its ancestor $G$. tosaensis in the type locality of the Calabrian Stage (the base of the Pleistocene) in Sta. Maria di Catanzaro, Southern Italy, has recently been investigated by various authors including Bayliss (1969),
Lamb (1969), Bandy and Wilcoxson (1970), and Poag (1971). The evolution of $G$. truncatulinoides was studied in detail in a deep-sea core from the central North Atlantic by Phillips et al. (1968) and more recently in Pliocene-Pleistocene sections of New Zealand by Hornibrook (in press).

In addition to the Globorotalia mentioned above, some other planktonic index species were investigated and their stratigraphic distribution recorded.

The figured specimens are deposited at the Museum of Natural History, Basel, under the numbers C3004330140 .

\section{LOCATION, SEDIMENTOLOGY, AND PALEOECOLOGY OF SITE 262}

Leg 27 investigated the eastern part of the northern Indian Ocean. Site 262, the easternmost of this leg, is located at $10^{\circ} 52.19^{\prime} \mathrm{S}, 123^{\circ} 50.78^{\prime} \mathrm{E}$ in the Timor Sea. At a water depth of 2298 meters, the site penetrated 442 meters of sediments with a total recovery of 365.5 meters $(82.69 \%)$.

The geology, morphology, and sedimentology of this area have been described by van Andel and Veevers 
(1967). The sediments of the Timor Trough are uniform, fine-grained, silty clays. They are separated from the southern Sahul Shelf area by a narrow zone of calcilutite on the continental slope. The carbonate content of the trough sediments decreases regularly from about $80 \%$ at the shelf edge to $15 \%-20 \%$ near the northern margin. This shows that fine carbonate detritus is transported from the Sahul Shelf through the Timor Trough. The silt content is in inverse proportion to the carbonate and increases from south to north, originating from the northern islands of Timor and Roti (see Figure 1). Planktonic organisms are predominant in the sediments of the trough area. Benthonic foraminifera are frequent only above 365 meters ( 200 fathoms). Radiolaria show an inexplicable distribution in surface sediments. Below 900 meters their percentage increases rapidly and forms up to $50 \%-70 \%$ of the coarser fraction below 2000 meters. This pattern closely follows the topography of the trough and does not seem to be influenced by sorting or solution (van Andel and Veevers, 1967).

The sedimentary section at Site 262 provides a variety of sedimentary environments. The oldest beds represent a shallow-water environment and change upwards into sediments of the shelf region. The open-sea influence increased gradually and by the middle Pleistocene deepwater conditions were reached. The scarcity of benthonic foraminifera, beginning from Core 31 upwards, may be explained by a deficiency in oxygen resulting from restricted circulation.

\section{Samples 47, CC-45-1, 106-108 cm}

Lithified to semilithified, yellowish-gray biogenous calcarenite with strong dolomitic recrystallization, common mollusc debris, and benthonic shallow-water foraminifera (Amphistegina, Operculina, Cellanthus, and Pararotalia) but only sporadic planktonic foraminifera. The samples indicate warm, shallow-water conditions with a maximum depth of 50-70 meters. Detrital quartz and mica, indicating terrigenous influence, is present in the finest fraction $(40 \mu-60 \mu)$ of Sample $45-1,106-108 \mathrm{~cm}$ through Core 37.

\section{Samples 45-1, 88-90 cm-44-2, $12-14 \mathrm{~cm}$}

Foraminiferal ooze, olive to grayish olive, components loosely cemented, almost without recrystallization. As in the lower interval, these sediments also contain shell fragments and benthonic foraminifera of shallow-water origin, but have a larger number of planktonic foraminifera compared to Unit 1 . The genus Pararotalia disappears at the top of the interval.

\section{Samples 43, CC-40-4, 62-64 cm}

Foraminiferal ooze, rich in nannofossils, grayish olive to olive, with preservation similar to the underlying interval. Planktonic foraminifera are dominant; the shallow-water benthonic foraminifera of Units land 2 are replaced by different genera such as Uvigerina and Bolivina. characteristic of the outer shelf and upper slope. Mollusc fragments are sparse.

Only in Sample 40, CC appear some shallow-water components such as Amphistegina, Balanidae. This occurrence could be due to slumping. The first evidence for a major subsidence of the Timor Trough is noted in this interval.

\section{Samples 40-2, 48-50 cm-37-3, 60-62 cm}

Nanno-foraminiferal ooze, sometimes rich in clay, grayish olive to grayish green. The fauna in clayey samples is well preserved. Planktonic foraminifera are dominant, benthonic ones are less abundant than in Unit 3, and small amounts of pteropoda are present. The top of this interval is characterized by the last occurrence of quartz and mica, the base by the first occurrence of pteropoda.

\section{Samples 36, CC-29, CC}

Clayey nanno ooze, grayish olive, without detrital quartz in the finest fraction. The dominantly planktonic foraminifera are excellently preserved. Benthonic foraminifera become scarce beginning with Core 31 . The base of this interval coincides with the PliocenePleistocene boundary, as defined by the evolution of the Globorotalia truncatulinoides lineage. The decrease in benthonic foraminifera indicates a further subsidence of the trough.

\section{Samples 29-5, 12-14 cm-17, CC}

Clayey nanno ooze, as in the interval above. From the base of this interval upwards, Radiolaria are continuously present. In comparison with the Recent distribution of Radiolaria in the Timor Trough (van Andel and Veevers, 1967), a depth below about 900 meters is indicated for this interval.

\section{Sample 16, CC-Core 1}

Grayish-olive Clay- and Radiolaria-rich nanno ooze. Radiolaria are predominant in Core 7 , with a percentage comparable to the Recent 1000 fathoms (about $1800 \mathrm{~m}$ ) Radiolaria percentage of van Andel and Veevers, (1967).

Fine detrital quartz and mica are present from Core 16 upward and a larger amount of apparently transported fine detrital carbonate is present from Core 13 to the top of the section.

The planktonic foraminifera fauna of Site 262 has a subtropical-tropical character throughout. In the lower part of the section, between Cores 45 and 31 , the groups of Globorotalia menardii, G. Crassaformis, G. tosaensis, and $G$. truncatulinoides show distinct and frequent changes in coiling direction. They could have been caused by climatic fluctuations. The concurrent presence of Hyalinea balthica does not clearly demonstrate colder conditions as assumed by some authors. The species occured in different climatic regions at a depth of 50-800 meters (Poag, 1971).

Globorotalia truncatulinoides is left coiling only in the lowermost part of the Pleistocene. Though the species is rare in the upper part of the section at Site 262, it appears to be right coiling throughout. An other interesting change in coiling direction from left to right occurs in the Globorotalia crassaformis group within Core 7. This level coincides with a strong increase in Radiolaria content. 


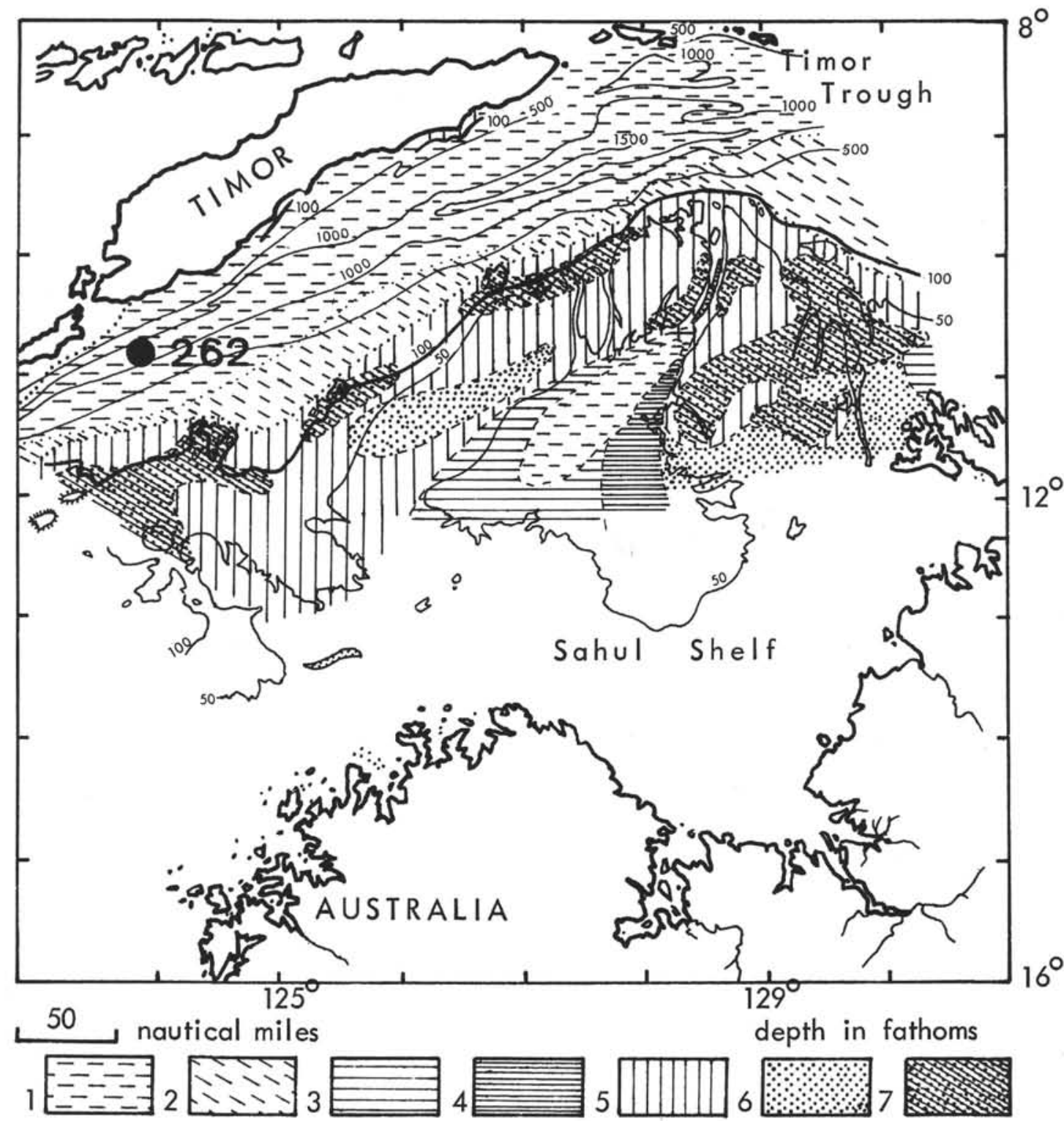

Figure 1. Bathymetry and facies distribution in the area of the Timor Trough and location of Site 262 (redrawn after Van Andel and Veevers, 1967, figs. 4.2 and 7.10). $1=$ Calcareous silty clay (11-50\% $\left.\mathrm{CaCO}_{3}\right) ; 2=$ Very terrigenous silty calcilutite $\left(51-75 \% \mathrm{CaCO}_{3}\right) ; 3=$ Calcareous sandy clay $(11-50 \%$ $\left.\mathrm{CaCO}_{3}\right) ; 4=$ Very terrigenous sandy calcilutite $\left(51-75 \% \mathrm{CaCO}_{3}\right) ; 5=$ Muddy calcarenite $(51-75 \%$ $\left.\mathrm{CaCO}_{3}\right) ; 6=$ Muddy calcarenite $\left(76-90 \% \mathrm{CaCO}_{3}\right) ; 7=$ Calcarenite $\left(91-100 \% \mathrm{CaCO}_{3}\right)$.

\section{BIOSTRATIGRAPHIC ZONATION}

A planktonic foraminiferal zonation based on the scheme proposed by Bolli and Premoli Silva (1973) was attempted. Although the nominate taxa of the zones or subzones are sometimes absent, other index forms are mostly present. The zonation was also compared with the zones of Blow (1969) and Berggren (1973) (see Figure 2).

?Globorotalia margaritae-Globorotalia miocenica Zone lower part

Samples 47, CC-45-1, 106-108 cm

The deepest beds of Site 262 contain only a few planktonic foraminifera. The occurrence of Pulleniatina obliquiloculata primalis, Globoquadrina altispira, Spaheroidinella dehiscens, Globigerinoides obliquus extremus, and Globorotalia multicamerata indicates that these shallow-water sediments were likely deposited within the uppermost part of the Globorotalia margaritae Zone. All these species range into the lowermost part of the Globorotalia miocenica Zone. The absence of $G$. margaritae within this interval could be due to solution of these thin-walled specimens.

\section{Globorotalia miocenica Zone}

Samples 45-1, 88-90 cm-41-5, 76-78 cm

The base of this zone is defined by the extinction of Globorotalia margaritae, the top by the dissappearance 
F. ROGL

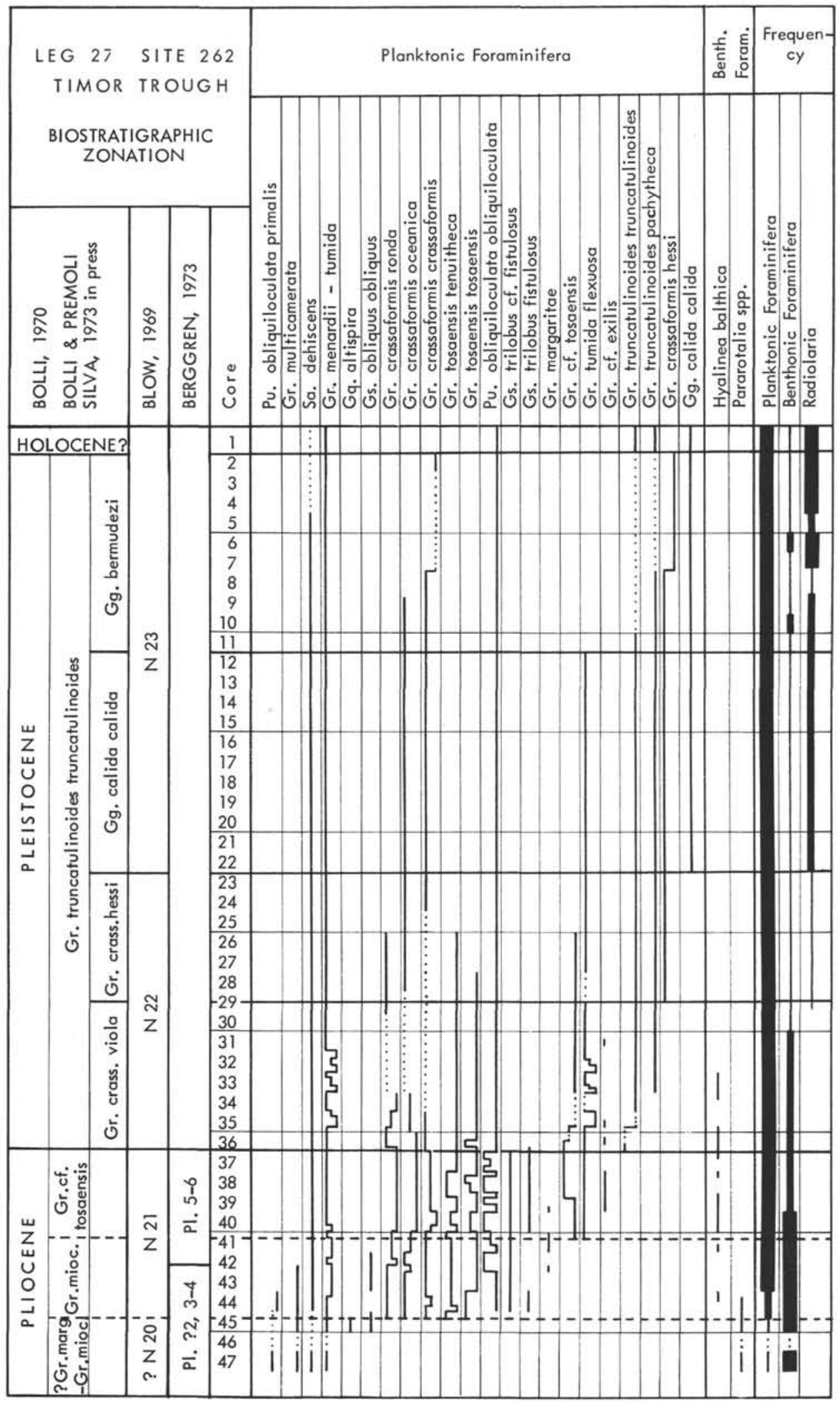

Figure 2. Biostratigraphic zonation based on planktonic foraminifera. The coiling direction of certain species is shown as follows: line on left side of column indicates left coiling, on right side, right coiling and in center, random coiling. The frequency of foraminifera and Radiolaria is shown in the columns at right: a thin line indicates rare; a medium line, common; and a broad line, abundant. 
of $G$. miocenica. Both marker species are missing at Site 262 , but the extinction in this interval of $G$. multicamerata and Globigerinoides obliquus extremus indicates the existence of this zone.

\section{Globorotalia cf. tosaensis Zone \\ Samples 41-2, 55-57 cm-37-3, 60-62 cm}

Since Globorotalia miocenica is missing, the base of this zone is tentatively drawn with the appearance of $G$. cf. tosaensis. According to Bolli (1970) this species appears in the upper part of the Globorotalia miocenica Zone.

\section{Globorotalia truncatulinoides truncatulinoides Zone Sample 36, CC-top of Core 1}

The Pliocene-Pleistocene boundary is defined by the first appearance of Globorotalia truncatulinoides truncatulinoides and coincides with the base of this zone. This zone, which represents the entire Pleistocene and Recent is subdivided into the following subzones of Bolli and Premoli Silva (1973):

\section{Globorotalia crassaformis viola Su-zone} Samples 36, CC-29, CC

This subzone represents the lower part of the Pleistocene between the first appearance of Globorotalia truncatulinoides truncatulinoides and the first appearance of Globorotalia crassaformis hessi. The nominate species G. crassaformis viola is not present at Site 262 .

\section{Globorotalia crassaformis hessi Subzone}

Samples 29-5, 12-14 cm-23, CC

The zone lies between the first appearances of Globorotalia crassaformis hessi and of Globigerina calida calida. All subspecies of Globorotalia tosaensis and $G$. crassaformis ronda become extinct within this zone.

\section{Globigerina calida calida Subzone Samples 22, CC-12, CC}

The typical, modern Globigerina calida calida appears in Core 22. The upper limit of the zone is defined by the upper limit of Globorotalia tumida flexuosa, which disappears in Core 12. The chronological equivalence of the upper limit of this subzone with that in the Caribbean and Atlantic is not certain.

\section{Globigerina bermudezi Subzone Samples 11, CC-2, CC}

This zone ranges from the upper limit of Globorotalia tumida flexuosa to the base of the Recent (Globorotalia fimbriata Subzone) as defined by Bolli and Premoli Silva (1973). The nominate taxon Globigerina bermudezi seems to be more or less an endemic Caribbean species of Late Pleistocene-Recent age. A distinct event within this subzone occurs between Cores 8 and 7. All subspecies of Globorotalia crassaformis change the coiling direction from left to right and $G$. truncatulinoides disappears.

\section{Globorotalia fimbriata Subzone Core 1}

A discontinuity in faunal distribution occurs between Cores 1 and 2. The subspecies of Globorotalia crassaformis, especially G. crassaformis hessi, not known from the Recent, disappear. The Globorotalia truncatulinoides subspecies reappear in this core after an absence in the interval of Cores 7-2. Because the zonal marker is missing, the age assignment is questionable.

\section{Correlation with the Zonal Scheme of Blow (1969)}

The zonation of the Plio-ene by Blow and his boundaries between the zones N19 to N21 are somewhat dubious (Bolli, 1970; Berggren, 1973). However, a tentative correlation with this scheme is attempted in Figure 2.

\section{Correlation with the Pliocene Zones of Berggren (1973).}

Berggren (1973) proposed a subdivision of the Pliocene into six zones and correlated these with paleomagnetic events and absolute ages. These zones can partially be applied to Site 262 . It is possible that the base of the section at Site 262 corresponds to the upper part of Zone Pl. 2 (extinction of Globigerina nepenthes to the extinction of Globorotalia margaritae). Zone Pl. 3 (extinction of Globorotalia margaritae to the extinction of Sphaeroidinellopsis) could be present in the lower part of the section at Site 262 because the extinction level of Sphaeroidinellopsis lies near or slightly below the appearance of Pulleniatina obliquiloculata (Core 44). Zone Pl. 3 cannot be separated from Zone Pl. 4 at Site 262. Zone Pl. 4 ranges up to the extinction of Globoquadrina altispira and Globorotalia multicamerata. This boundary lies at Sample 42, CC. A distinction between Zones PI. 5 and Pl. 6 is not possible at Site 262 because Globorotalia miocenica is missing.

Correlation with nannoplankton zonation of Proto Decima (this volume)

Ages based on nannoplankton zonation at Site 262 differ somewhat from these on foraminifera, especially at the Pliocene-Pleistocene boundary. The lowermost part of Site 262 is barren of nannoplankton. Discoaster brouweri is abundant up to Core 44 , Section 3 , but disappears or becomes scarce in higher cores; its appearance above Core 44 is probably due to reworking. The interval of Cores $43-30$ is placed in the Pseudoemiliania lacunosa Zone. Its upper limit corresponds with the base of the Globorotalia crassaformis hessi Subzone. Cores 29-10 belong to the Gephyrocapsa oceanica Zone and include the Globorotalia crassaformis hessi, and Globigerina calida calida, and the lowermost part of the Globigerina bermudezi subzones. Cores 9-1 belong to the Emiliania huxleyi Zone.

\section{EVOLUTION OF GLOBOROTALIA TRUNCATULINOIDES IN SITE 262.}

Takayanagi and Saito (1962) erected the new species Globorotalia tosaensis in their paper on the planktonic foraminifera from the Pliocene of the Nobori Formation (Japan). They assumed that the evolution from their new unkeeled and rounded species leads to Globorotalia truncatulinoides with a peripheral thickened keel and acute periphery.

Later, Banner and Blow $(1965,1967)$ used this evolution in their zonal scheme for the definition of the base of the Pleistocene and of the zones N21 and N22. 
The first detailed study on the evolution of Globorotalia truncatulinoides was made by Phillips et al. (1968) in the deep-sea core Chain 61 (171) from the North Atlantic. Globorotalia tosaensis is present there in the lowermost part of the core together with transitional forms to Globorotalia crassaformis, from which it evolved. Two groups within Globorotalia tosaensis can be distinguished. One is rounded and represents the typical $G$. tosaensis; the other is subangular, with a flat spiral side, leading to transitional forms between $G$. tosaensis and G. truncatulinoides. The evolution of Globorotalia truncatulinoides from specimens with an imperforate, weakly developed keel to characteristic specimens of this species takes place between 530 and $500 \mathrm{~cm}$ of the Chain core, or within the upper part of Olduvai Event. The characteristics of Globorotalia truncatulinoides after Phillips et al. (1968) are: larger, more robust, smoother walled test than in $G$. tosaensis; development of a peripheral imperforate keel; a higher, more acutely angular outline in side view; apertural face depressed in a sulcus; a more evolute coiling with a more open umbilicus and steep walls along the umbilical margin; sometimes a thickened umbilical collar around the umbilical shoulder; in morphologically more advanced specimens, an imbricating chamber arrangement is possible. The same development of Globorotalia truncatulinoides is also seen at Site 262 .

The different morphologic types leading to $G$. truncatulinoides were described by Blow (1969). He postulated one evolutionary lineage comprising Globorotalia crassaformis crassaformis and G. truncatulinoides pachytheca.

The evolution of the $G$. truncatulinoides group within Site 262 is shown on Figure 3 and on Plates 1 and 2. The early part of the evolutionary sequence, Globorotalia tosaensis evolving from $G$. crassaformis, is not seen at Site 262, probably due to adverse facies conditions in the lowermost part of the drilled section. G. crassaformis s.l. and G. tosaensis s.l. occur in Sample 45-1, 88-90 cm together with transitional forms. Such forms also occurred in the lower part of Chain 61 (171) (Phillips et al., 1968 ) and in New Zealand (Hornibrook, in press). G. tosaensis began in New Zealand in the late Pliocene above the Waipipian Stage, with a similar form referred to G. crassaformis by Hornibrook. As at Site 262, this $G$. crassaformis is distinguished from $G$. tosaensis by possessing only four chambers in the final whorl.

Left-coiling G. crassaformis occur in the lower part of the Globorotalia miocenica Zone in the Java well Bodjonegoro, 1 308-291 meters (Bolli, 1966, 1970). Higher, at 286 meters, the coiling is random. Rightcoiling specimens, transitional between typical $G$. crassaformis crassaformis and $G$. tosaensis tosaensis are present between 278 and 272 meters. Right-coiling typical $G$. tosaensis occur between 255 and 204 meters, corresponding to the upper part of the Globorotalia miocenica Zone. Only left-coiling $G$. crassaformis are present in the uppermost part of that section $(101 \mathrm{~m})$. The material shows a transition from G. crassaformis crassaformis similar to that figured by Galloway and Wissler (1927) and Blow (1969) to G. tosaensis tosaensis.

\section{TAXONOMIC NOTES}

The evolution of Globorotalia tosaensis at Site 262 seems to have its origin in a small type of $G$. crassaformis with flattened spiral side (Plate 1, Figures 1-3). The following taxa can be distinguished.

Globorotalia sp.

Intermediate between $G$. crassaformis and $G$. tosaensis tenuitheca (Plate 1, Figures 1-3)

With four chambers in the last whorl, these transitional forms are closer to $G$. crassaformis. The tangentially rather elongate chambers are separated on the spiral side by moderately curved, intercameral sutures, running nearly tangentially to the earlier whorl. The umbilicus is small, almost closed. The coiling is random.

This form occurs in small numbers in the lower part of the section (Cores 45-40) together with $G$. crassaformis crassaformis and $G$. tosaensis tenuitheca.

\section{Globorotalia tosaensis tenuitheca Blow}

(Figures 3, No. 1-9; Plate 1, Figures 4-8)

The test is planoconvex with a moderately conical umbilical side and five chambers in the last whorl. The intercameral sutures are radial, straight to slightly curved on the spiral side. The periphery is subacute to sharply angular, without keel, but with the beginning of a keel or imperforate margin in younger samples. This is also shown by Blow (1969, pl. 4, fig. 16-17; pl. 40, fig. 3). The peripheral outline is subcircular to slightly angular, not lobate. The umbilicus is small, similar to that of Globorotalia crassaformis s.l. in stratigraphically older specimens, becoming more open in younger ones. The wall is thin, transparent, with small pustules.

The direction of coiling is variable from Samples $45-1,88-90 \mathrm{~cm}$ to $38-1,49-51 \mathrm{~cm}$. Above this interval, and continuing to the top of the subspecies (Sample 26, CC) it is to the right. Forms transitional to Globorotalia truncatulinoides truncatulinoides first appear in Core 39.

\section{Globorotalia tosaensis tosaensis Takayanagi and Saito, 1962}

(Figure 3, No. 10-12; Plate 1, Figures 9-12)

The test also has five chambers in the final whorl, but they are more inflated than in $G$. tosaensis tenuitheca. The umbilical side is rounded, subconical, and the peripheral margin possesses a broad rounded shoulder. The peripheral outline is circular, somewhat lobate. In contrast to $G$. tosaensis tenuitheca, the intercameral sutures both on the spiral and umbilical side are more strongly curved, and the umbilicus is wider. The wall is transparent, but more robust and with stronger pustulation than in G. tosaensis tenuitheca.

The coiling direction is variable between Cores 45 and 36 , but remains dominantly to the right $G$. tosaensis tosaensis first appears in the same sample as $G$. tosaensis tenuitheca but ranges only to Core 28 .

\section{Globorotalia cf. tosaensis Takayanagi and Saito, 1962}

(Figure 3, No. 13-15; Plate 1, Figures 13-18)

The original description and figures by Takayanagi and Saito of $G$. tosaensis show fairly thin-walled specimens with a slightly rounded to slightly subacute peripheral margin. The same features are present in paratypes received, and also in specimens from the Java well Bodjonegoro-1, determined as G. tosaensis by T. Saito.

Phillips et al. (1968) include in G. tosaensis forms with distinctly thicker walls and more rounded peripheral margins. These more robust types were also included by Blow (1969) in his concept of $G$. tosaensis tosaensis. Bolli (1970) separated these thick-walled forms from $G$. tosaensis by naming them $G$. truncatulinoides $\mathrm{cf}$. tosaensis. He also used this taxon as a zonal marker for his upper Pliocene Globorotalia truncatulinoides $\mathrm{cf}$. tosaensis Zone. Unfortunately, the specimens from Chain 61 figured by Bolli (1970, pl. 3, fig. 16-18) as $G$. truncatulinoides $\mathrm{cf}$. tosaensis are nearly four-chambered, while most specimens of $G$. cf. tosaensis possess five chambers in the last whorl.

Primitive Globorotalia of. tosaensis resemble G. tosaensis tosaensis with thickened walls, but differences are pronounced in advanced specimens. The chambers of the last whorl of $G$. cf. tosaensis are strongly inflated on the spiral side, rising above the earlier whorls. The periphery is rounded, occasionally with a truncated edge, simulating a keel (Plate 1, Figure 16). The outline in spiral view is subcircular to 
slightly angular. Some advanced specimens also resemble initial forms of $G$. truncatulinoides pachytheca.

The range of this species at Site 262 is not continuous. It begins with scarce, isolated, small and axially compressed, right-coiling specimens (Samples 41-2, 55-57 cm-39-5, 55-57 cm. A first left-coiling maximum occurs between Samples 37-3, 60-62 cm-36-6, $81-83 \mathrm{~cm}$. In Sample 36, CC all G. tosaensis tosaensis are right coiling in contrast to the left coiling of $G$. cf, tosaensis, which again becomes right coiling and has a second maximum of frequency in Cores 33-26.

Globorotalia truncatulinoides truncatulinoides (d'Orbigny, 1839)

(Figure 3, No. 16-21; Plate 2, Figures 1-3, 7-10)

Transitional forms between $G$. truncatulinoides truncatulinoides and G. tosaensis tenuitheca occur in Cores 39-37. A separation of these two subspecies is nearly impossible in Sample 37-3, 60-62 cm, where many specimens have a fully developed keel, except for the last chamber. Specimens are fully keeled throughout from Core 36 to the top.

In the lower part of its appearance, Globorotalia truncatulinoides truncatulinoides occurs only in small numbers. These tests are small, moderately high conical on the umbilical side and with a fairly wide umbilicus. A fully developed, but thin keel surrounds the sharply angular peripheral margin, the peripheral outline in spiral view is subcircular to angular. The wall is thin and transparent with sparsely distributed pustules. Larger specimens appear in Core 29, where Radiolaria first occur.

The modern population consists of large, widely coiled tests with robust walls. The umbilicus is wide, open, sometimes with a collar of pustules around its margin. The apertural face of the last chamber shows a broad identation (sulcus). The spiral surface is frequently concave resulting from an elevated peripheral edge of the last chambers.

Globorotalia truncatulinoides truncatulinoides coils to the left in the lower part of Core 36; it is absent in Samples 36-4, 62-64 cm-35-4, $122-124 \mathrm{~cm}$, and returns to right coiling in Sample $35-2,81-83 \mathrm{~cm}$. The maximum abundance lies between Cores 30-26; it occurs only sporadically in the upper part of the section at Site 262 .

\section{Globorotalia truncatulinoides pachytheca Blow, 1969}

(Figure 3, No. 22-24; Plate 2, Figures 4-6, 11-13)

This subspecies and $G$. truncatulinoides truncatulinoides are nearly fully developed in Sample 37-3, 60-62 cm. The differences between $G$. cf. tosaensis and $G$. truncatulinoides pachytheca are small in Cores 37 and 36. Both are absent in the upper part of Cores 36-34. The subspecies is well developed and occurs in large numbers in Core 33, where it has a thick wall, a broad conical truncated umbilical side with somewhat inflated chambers, and a thick keel. The umbilicus is wide and open. The intercameral sutures on both sides are less curved compared with $G$. cf. tosaensis. In the deeper samples the test is, in comparison with $G$. cf. tosaensis. In the deeper samples the test is, in comparison with $G$. truncatulinoides truncatulinoides, more robust, larger, with a more inflated umbilical side and a wider umbilicus. The modern specimens do not reach the size and wide coiling of $G$. truncatulinoides truncatulinoides. The peripheral outline is more circular, the chambers are more appressed and the umbilicus is smaller. A separation of the subspecies truncatulinoides and pachytheca may well be justified, since they appear to be morphologically distinct throughout the range of the species.

Only in Core 37 is a form close to G. truncatulinoides pachytheca left coiling, in all younger samples it is right coiling. Its frequency is nearly the same as for $G$. truncatulinoides truncatulinoides, with a maximum in Cores 33-26.

\section{GLOBOROTALIA CRASSAFORMIS GROUP AT SITE 262}

Core 45 is the deepest core with rich plankton. Globorotalia crassaformis crassaformis, G. crassaformis oceanica, and $G$. crassaformis ronda appear here together. These subspecies remain small in the lower part of the section and become larger above the Pliocene-Pleistocene boundary.

$G$. crassaformis hessi seems to branch off from $G$. crassaformis ronda in the lower part of the Pleistocene. This evolutionary step is characterized by wider coiling and the appearance of a reduced flattened final chamber in the subspecies hessi.G. crassaformis hessi has possibly also derived from the thin-walled $G$. crassaformis oceanica through thickening of the walls.

A more axially compressed form, which shows wider coiling than $G$. crassaformis hessi, appears in Core 26. It resembles G. crassaformis cf. viola of Bolli (1970). Through further flattening of the test of $G$. crassaformis cf. viola, a form evolves which appears close to the lower Pliocene $G$. crotonensis.

The interrelations and evolution of these taxa cannot be demonstrated within one profile alone. Common features of all the $G$. crassaformis subspecies at Site 262 are the absence of a true imperforate keel and synchronous coiling changes.

\section{TAXONOMIC NOTES}

\section{Globorotalia crassaformis crassaformis (Galloway \& Wissler, 1927)} (Figure 4, No. 1-6; Plate 3, Figures 1-5)

In addition to specimens almost identical to that figured by Galloway and Wissler there are also present in the Pliocene of Site 262, specimens with a strongly flattened spiral side and a rectangular equatorial outline. All specimens are small in the lower part of the section.

The coiling direction is variable between Cores 45 and 40 , with a preference for left-coiling specimens. Specimens in Cores 39 to 35 show mainly random coiling. The $G$. crassaformis group is absent between Cores 34 and 23.

The earliest part of the Globorotalia crassaformis evolution is not seen at Site 262. G. crassaformis crassaformis is already present with small specimens in the lower part of the section (Figure 4, No. 1-6). $G$. crassaformis oceanica, distinguished by more inflated chambers, shows a distinct increase in test size above the Pliocene-Pleistocene boundary (Figure 4, No, 7-12). The thick-walled $G$. crassaformis ronda is well developed (Figure 4. No. 13-15). G. crassaformis hessi develops via transitional forms from $G$. crassaformis ronda and first reaches its typical form in the middle Pleistocene (Figure 4, No. 16-21). G. crassaformis cf. viola (Figure 4, No. 22-24) and G. aff. crotonensis (Figure 4, No. 25-27) were found to derive from the $G$. crassaformis ronda- $G$. crassaformis hessi lineage at Site 262.

A well-developed left-coiling population is present between Cores 24 and 8 . Right-coiling specimens were found only in Core 2 .

\section{Globorotalia crassaformis oceanica Cushman and Bermudez, 1949}

(Figure 4, No. 7-12; Plate 3, Figures 19-21)

This subspecies is distinguished from $G$. crassaformis crassaformis by more inflated chambers, a more rounded peripheral margin, and a larger umbilicus. It conforms to paratype material received from P. J. Bermudez (see also remarks on this species by Blow, 1969, p. 348). The small specimens in the lower part of the section at Site 262 show similarities to thin-walled $G$. crassaformis ronda, but differ in the more rectangular equatorial outline and lesser chamber breadth (Plate 3 , Figure 6). The distribution is similar to that of $G$. crassaformis crassaformis.

\section{Globorotalia crassaformis ronda Blow, 1969}

(Figure 4, No. 13-15; Plate 3, Figures 7-18)

The subspecies ronda begins, like oceanica, with small specimens. They have a flat spiral side, are slightly rectangular in outline and resemble $G$. crassaformis oceanica (Plate 3, Figures 7, 8). A form with wider coiling, thick walls and narrower chambers (Plate 3, Figures 9, $10)$ that appears in smaller numbers is also included in ronda. Welldeveloped $G$. crassaformis ronda specimens show tight coiling, strongly appressed chambers, a small, almost closed umbilicus, and a thick wall.

The subspecies is dominantly left coiling from Core 45 to the lower part of Core 42, it coils at random in Cores 42,41 , and to the right in Cores 40-36. After a short random- to left-coiling episode in Cores 36 and 35 it is right coiling again in Core 34 . The subspecies is absent between Cores 33 and 30, where the other subspecies of $G$. crassaformis are also missing. In its highest occurrence (Cores 29-26), it is left coiling, like the other subspecies of $G$. crassaformis. 


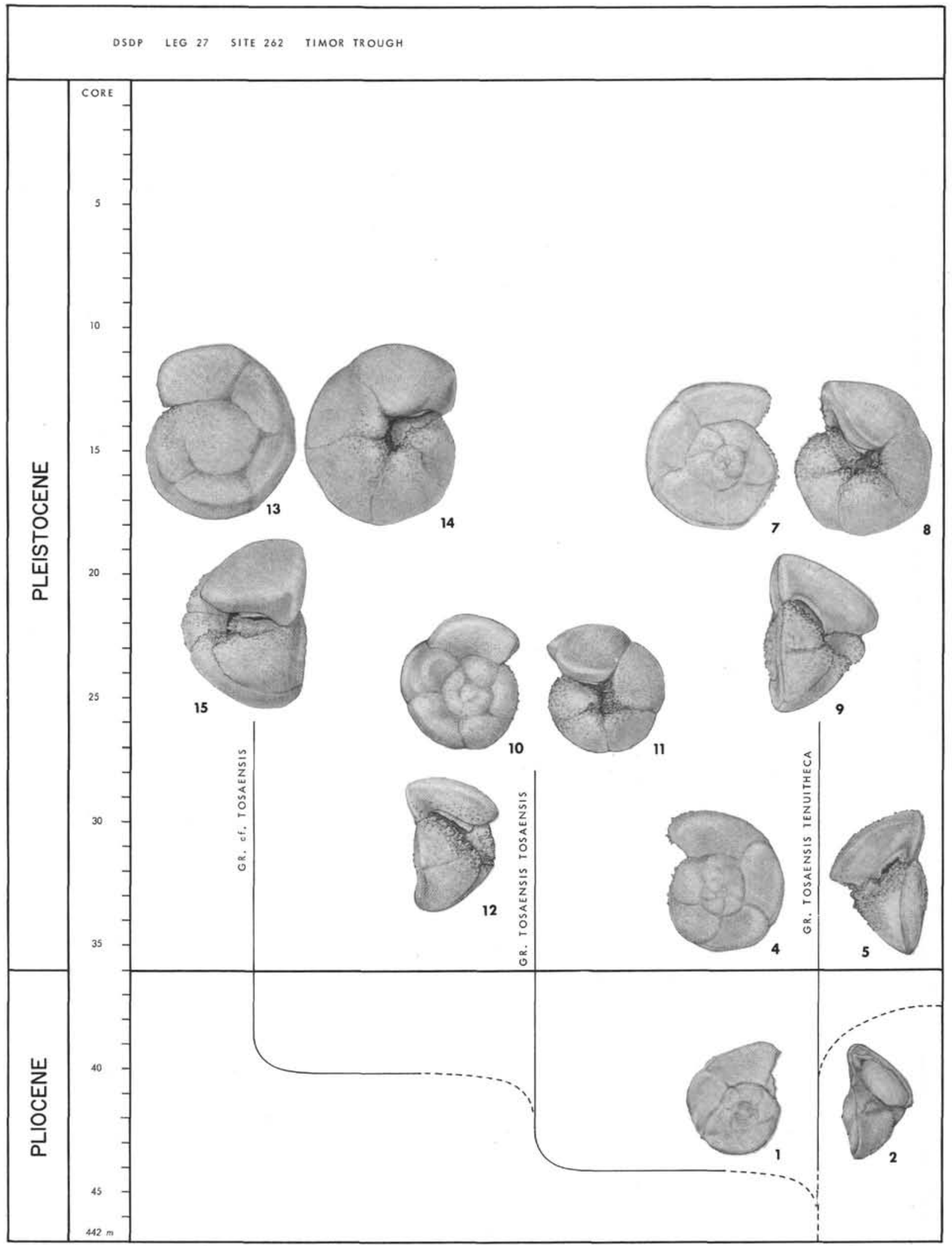

Figure 3. The Evolution of the Globorotalia truncatulinoides group. 1-9: Globorotalia tosaensis tenuitheca Blow (1-3: Sample 45-1, 88-90 cm; 4-6: Sample 38, CC; 7-9: Sample 34-1, 89-91 cm). 10-12: Globorotalia tosaensis tosaensis Takayanagi and Saito (Sample 37-5, 86-88). 13-15: Globorotalia cf. tosaensis Takayanagi and Saito (Sample 31-4, 60-62 cm). 16-21: Globorotalia truncatulinoides truncatulinoides (d'Orbidny) (16-18: Sample 36, CC; 19-21: Sample 14, CC). 22-24: Globorotalia truncatulinoides pachytheca Blow (Sample 28, CC) Specimens 1-15 show the three different forms of Globorotalia tosaensis. A gradual increase 


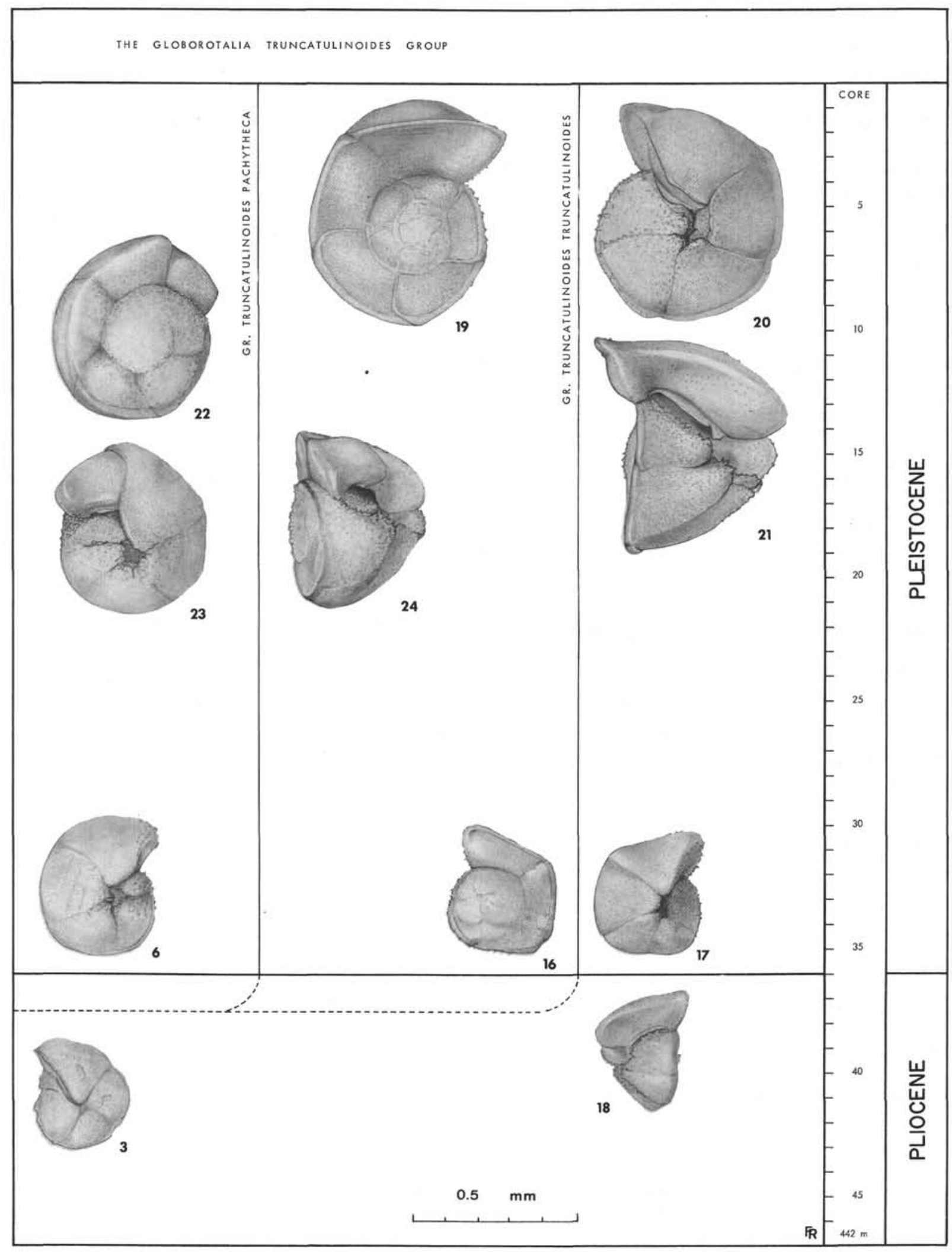

in test size and umbilical opening takes place within the evolution of $\mathrm{G}$. tosaensis, tenuitheca (Specimens 1-9). The more rounded thin-walled G. tosaensis tosaensis (Specimens 10-12) leads to the robust G. cf. tosaensis (Specimens 13-15). Small G. truncatulinoides truncatulinoides develop from G. tosaensis tenuitheca with a flat spiral side (Specimens 16-18). This species reaches its full development in late Pleistocene (Specimens 19-21). The thick-walled G. truncatulinoides pachytheca develops in the Pleistocene from the same lineage (Specimens 22-24). 
Globorotalia sp.

Intermediate between $G$. crassaformis ronda and $G$. crassaformis hessi (Plate 4, Figures 1-7)

Beginning with Core 36 a more widely coiled form appears within populations of $G$. crassaformis ronda, showing a reduced, axially compressed final chamber. On the umbilical side the chambers are better separated by nearly straight, radially incised sutures. The umbilicus is wider and more open than in $G$. crassaformis ronda. This intermediate form leads to $G$. crassaformis hessi and concurs partially with it.

Globorotalia crassaformis hessi Bolli and Premoli Silva, 1973

(Figure 4, No. 16-21; Plate 4, Figures 8-19)

The subspecies is characterized by a fairly rectangular equatorial outline. The peripheral margin is more acute compared with G. crassaformis ronda. The spiral side is flat to slightly concave, the last few chambers with an elevated outer margin. The final chamber is frequently reduced and axially compressed, with an acute margin. The umbilicus is deep and comparatively small. The robust wall is covered by well-developed pustules, which often form a thick layer. Only the last reduced chamber is usually thin and transparent. The peripheral margin does not possess a true imperforated keel, but sometimes a partial thickening.

The species is left coiling from Cores 29-8. An instantaneous switch to right coiling occurs in Core 7 and persists to Core 2. The species is absent in Core 1.

Globorotalia crassaformis ef. viola Blow, 1969

(Figure 4, No. 22-24; Plate 5, Figures 1-9, 13-14)

A form similar to that described as $G$. crassaformis cf. viola from DSDP Leg 4 by Bolli (1970) appears in Core 26. Similar, unkeeled specimens are figured by Jenkins and Orr (1972) from DSDP Leg 9 as $G$. crassula. However, the typical $G$. crassula crassula Cushman and Stewart and $G$. crassula viola Blow are characterized by a welldeveloped keel.

G. crassaformis cf. viola seems to develop from intermediate forms between $G$. crassaformis ronda and $G$. crassaformis hessi. These ancestors of $G$. crassaformis cf. viola have a tighter coiling and a more rounded peripheral margin.

The axially compressed planoconvex test has four to four and half chambers in the last whorl. The spiral side is flat to moderately vaulted. The equatorial outline is subcircular, fairly lobate, with an unkeeled subangular peripheral margin. The intercameral sutures on the spiral side are slightly curved and incised. The umbilical side is broadly rounded and has radial, straight sutures. The umbilicus is fairly large and deep. The aperture is a low arch bordered by a distinct lip. Sometimes the final chamber is slightly reduced.

G. crassaformis cf. viola ranges from Core 26 to Core 12 where it is left coiling. In a last isolated occurrence in Core 7 it is right coiling.

Globorotalia aff. crotonensis Conato and Follador, 1967

(Figure 4, No. 25-27; Plate 5, Figures 10-12, 16-22)

Deriving from the thin-walled, more lobate $G$. crassaformis $\mathrm{cf}$. viola (Plate 4, Figures 1, 2, 6, 7), the test of this form is axially further compressed. The chambers are broader in radial direction, have a more circular peripheral outline, resulting in the equatorial periphery being broadly lobate. The chambers are somewhat imbricated on the spiral side and the sutures are more strongly curved compared with $G$. crassaformis cf. viola. The wall is thin and transparent, but with discrete pustules. A comparison with paratype material supplied by $\mathrm{U}$. Follador (collection of H. M. Bolli) suggests that the Site 262 specimens are identical with $G$. crotonensis, described from the lower Pliocene of Italy, but not known to occur there in the Pleistocene. Reworking is unlikely since there is no other indication of reworking in this part of Site 262. It would also be difficult to understand why a reworked species should follow the same changes in coiling direction as do all other subspecies of $G$. crassaformis in this part of Site 262.

The species is left coiling from Cores 22-9, and changes to right coiling in Cores 7-3. This change is regarded as good evidence for connecting this form with the subspecies of $G$. crassaformis, which follows the same coiling patterns.

Evolutionary features common to both the $G$. truncatulinoides and the $G$. crassaformis lineage were observed at Site 262 .

Originating from the thin-walled, spirally flattened $G$. crassaformis crassaformis, a development of several subspecies took place in the lower Pliocene. The first form evolving from G. crassaformis crassaformis, G. crassaformis oceanica was also thin walled, but had more inflated chambers and a broadly rounded peripheral margin.
Next developed $G$. crassaformis ronda with thicker walls, tighter coiling more appressed chambers, and a smaller umbilicus.

A similar evolutionary sequence of features took place in the Glohorotalia tosaensis lineage in the later Pliocene. The thin-walled $G$. tosaensis tenuitheca, the broadly rounded G. tosaensis tosaensis, and the thick-walled $G$. cf. tosaensis developed here within a short stratigraphic interval.

A third evolutionary lineage initiated from $G$. tosaensis tenuitheca at the beginning of the Pleistocene, G. truncatulinoides truncatulinoides is the thin walled and $G$. truncatulinoides pachytheca the thick-walled subspecies.

Three morphological types each can thus be distinguished in the $G$. crassaformis and G. tosaensis lineage, against two in the $G$. truncatulinoides lineage.

\section{REMARKS ON OTHER PLANKTONIC FORAMINIFERA}

Distribution of selected planktonic foraminifera is shown in Figure 5 .

\section{Globorotalia cf. exilis Blow}

Specimens resembling G. exilis occur in Cores 39-38 and later as isolated forms in Cores 36,35 , and 30 . They are thin-walled, with a strongly lobate equatorial outline, but contrary to the typical $G$. exilis from the Caribbean, they coil to the left. According to Blow (1969), $G$. exilis ranges from Zone $\mathrm{N} 18$ to $\mathrm{N} 21$ (? N22); in the Caribbean area it ranges from the upper part of the Globorotalia margaritae Zone into the basal part of the Globorotalia cf. tosaensis Zone (Bolli and Premoli Silva, 1973). It is possible that the left-coiling specimens at Site 262 are comparable with the questionable occurrence in N22 of Blow. Jenkins and Orr (1972) also mention left-coiling exilis populations from the Pliocene of the eastern equatorial Pacific.

\section{Globorotalia margaritae Bolli and Bermudez}

The species is absent in the lower part of the section. Some isolated small specimens, present in Cores 42,41 , and 39 , are probably reworked.

\section{Globorotalia cultrata menardii-tumida tumida group}

The species of this group show no significant differences in occurrence and are here listed together. Modern G. culrata are dominant in the upper part of the Pleistocene section. The following coiling changes occur within the group: Left coiling from Cores 47-44; random coiling, with short left coiling interruptions, from Cores 4340; left coiling to Core 36 . In the lower part of the Pleistocene section, from Core 35-32, frequent fluctuations with right-coiling maxima occur. The species group is left coiling throughout from Core 31 to top.

\section{Globorotalia tumida flexuosa (Koch)}

The subspecies occurs in the Pliocene and in the Pleistocene up to Core 12. This top is here tentatively regarded as time equivalent with the well-established top in the Atlantic and Caribbean (Ericson and Wollin, 1956), although a simultaneous extinction of flexuosa in the Indopacific and Atlantic-Caribbean is not yet proven. Recent flexuosa-like types of thin-walled Globorotalia cultrata, were reported from the northern Indian Ocean by Bé and McIntyre (1970).

Globorotalia multicamerata Cushman and Jarvis

Right-coiling, small, delicate specimens, with a vaulted spiral side, close to this species, occur in Cores 47-45. The species is more typical in Cores 44-42. The top occurrence is defined by Berggren (1973) as the boundary between his Pliocene zones Pl. 4 and 5, which lies within the lower part of the Globorotalia miocenica Zone of Bolli (1970).

\section{Globigerina calida calida Parker}

Typical specimens with elongated chambers and a wide open umbilicus appear in Core 22. Specimens from cores immediately below are very similar but without the typical chamber elongation. The boundary between the Globorotalia hessi and the Globigerina calida calida subzones of Bolli and Premoli Silva (1973) and the base of Zone $\mathrm{N} 23$ of Blow (1969) are defined by the first appearance of this species.

\section{Globigerinoides trilobus fistulosus (Schubert)}

The subspecies appears in Core 44 and is again present in Cores 4036 (lower part). The characteristic form has well-separated fistules arranged in one plane on the equatorial periphery of the last chamber. The specimens with broader and weaker extensions, placed in 
Globigerinoides trilobus cf. fistulosus, occur in nearly the same interval (Cores 44-37). The subspecies has a restricted range in the Caribbean area from the upper part of Globorotalia margaritae Zone to the top of the Globigerinoides fistulosus Subzone of Bolli and Premoli Silva (1973). According to Blow (1969), it ranges from Zone N18 to N21. Following Berggren (1973), G. fistulosus becomes extinct only shortly after the appearance of Globorotalia truncatulinoides, or slightly above the Olduvai Event (about 1.8 m.y.).

G. trilobus fistulosus apparently has a slightly longer range in the Indopacific compared with that in the Caribbean where it disappears at the top of the middle Pliocene Globorotalia trilobus fistulosus Subzone.

\section{Globigerinoides obliquus obliquus Bolli}

The subspecies is frequent in Core 45 . Only isolated specimens occur above as high as Core 42 . The subspecies ranges in the Caribbean area into the lower Pliocene Globorotalia margaritae Zone (Bolli, 1970). In contrast, it continues to the top of the Pliocene or into the base of the Pleistocene after Berggren (1973), Blow (1969), and Jenkins and Orr (1972). An extinction within the middle Pliocene is probable at Site 262.

\section{Globigerinoides obliquus extremus Bolli and Bermudez}

This species occurs in the lower part up to Core 45 and thereafter sporadically until Core 41. This is in agreement with Blow (1969) and Bolli (1970) who give a range into Zone N21 or into the upper part of the Glohorotalia miocenica Zone.

\section{Globoquadrina altispira (Cushman and Jarvis)}

The isolated occurrence of this species within the lower part of Core 45 indicates that this part of the calcarenite could be uppermost Globorotalia margaritae or lowermost Globorotalia miocenica Zone.

Sphaeroidinella dehiscens (Parker and Jones)

The species occurs as small but well-developed specimens in Core 47. Sphaeroidinella begins within the Globorotalia margaritae Zone.

\section{Pulleniatina obliquiloculata s.I.}

A continuous succession of this species group is present in Site 262. It begins with Pulleniatina obliquiloculata primalis in the lowest part, represented by already highly developed specimens with right to random coiling (Cores 47-44). The transition to $P$. obliquiloculata obliquiloculata takes place in Cores $44-43$, where all specimens coil to the right. Frequent changes in right- and left-coiling preference of $P$. obliquiloculata obliquiloculata occur in Cores $42-37$, to the PliocenePleistocene boundary. The coiling remains to the right throughout the Pleistocene. Similar coiling changes in the Pliocene also exist in the Atlantic-Caribbean, DSDP Leg 4 (Bolli, 1970).

\section{ACKNOWLEDGMENTS}

Gratitude is expressed to H. M. Bolli (Leg 27 paleontologist, Zurich) for making available the material for investigation. Together with J. P. Beckmann (Zurich) he discussed the results and the manuscript. N. de B. Hornibrook (Lower Hutt, New Zeatand) kindly sent a preprint of his New Zealand Globorotalia truncatulinoides paper.

The laboratory facilities of the Geology Department, Swiss Federal Institute of Technology were used and H. E. Franz (Zurich) prepared the SEM micrographs. The project was supported by the Swiss National Science Foundation.

\section{REFERENCES}

Bandy, O. L. and Wilcoxson, J. A., 1970. The PliocenePleistocene boundary, Italy and California: Geol. Soc. Am. Bull., v. 81, p. 2939-2948.
Banner, F. T. and Blow, W. H., 1965. Progress in the planktonic foraminiferal biostratigraphy of the Neogene: Nature, v. 208, no. 5016, p. 1164-1166.

1967. The origin, evolution and taxonomy of the foraminiferal genus Pulleniatina Cushman, 1927: Micropaleontology, v. 13, p. 133-162.

Bayliss, D. D., 1969. The distribution of Hyalinea balthica and Globorotalia truncatulinoides in the type Calabrian: Lethaia, v. 2, p. 133-143.

Bé, A. W. H. and McIntyre, A., 1970. Globorotalia menardii flexuosa (Koch): An "extinct" foraminiferal subspecies living in the northern Indian Ocean. Deep-Sea Res.v.17, p. 595-601.

Berggren, W. A., 1973. The Pliocene time-scale: calibration of planktonic foraminiferal and calcareous nannoplankton zones: Nature, v. 243, no. 5407, p. 391-397.

Blow, W. H., 1969. Late middle Eocene to Recent planktonic foraminiferal biostratigraphy: Internatl. Conf. Plankt. Microfoss., Geneva, 1967, Proc., v. 1, p. 199-422.

Bolli, H. M., 1966. The planktonic foraminifera in well Bodjonegoro-1 of Java. Ecolog. Geol. Helv., v. 59, p. 449465 .

Bolli, H. M., 1970. The foraminifera of Sites 23-31, Leg 4. In Bader, R. G., Gerard, R. D., et al., Initial Reports of the Deep Sea Drilling Project, Volume 4: Washington (U.S. Government Printing Office) p. 577-643.

Bolli, H. M. and Premoli Silva, I., 1973. Oligocene to Recent planktonic foraminifera and stratigraphy of the Leg 15 sites in the Caribbean Sea. In Edgar, N. T., Saunders, J. B., et al., Initial Reports of the Deep Sea Drilling Project, Volume 15: Washington (U.S. Government Printing Office) p. $475-498$

Ericson, D. B. and Wollin, G., 1956. Micropaleontological and isotopic determinations of Pleistocene climates: Micropaleontology, v. 2, no. 3, p. 257-270.

Ericson, D. B., Ewing, M., and Wollin, G., 1964. The Pleistocene epoch in deep-sea sediments. Science, v. 146, no. 3645 , p. $723-732$.

Galloway, J. J. and Wissler, S. G., 1927. Pleistocene foraminifera from the Lomita Quarry, Palos Verdes Hills, California: J. Paleontol., v. 1, p. 35-87.

Hornibrook, N. de B., in press. Globorotalia truncatulinoides and the Plio-Pleistocene boundary in northern Hawkes Bay, New Zealand: Asano, Memorial Volume, Sendai, Japan.

Jenkins, D. G. and Orr, W. N., 1972. Planktonic foraminiferal biostratigraphy of the eastern equatorial Pacific, DSDP Leg 9. In Hays, J. D. et al., Initial Reports of the Deep Sea Drilling Project, Volume 9: Washington (U.S. Government Printing Office) p. 1059-1193.

Lamb, J. L., 1969, Planktonic foraminiferal datums and late Neogene epoch boundaries in the Mediterranean, Caribbean, and Gulf of Mexico. Gulf Coast Assoc. Geol. Soc. Trans., v. 19, p. 359-378.

Phillips, J. D., Berggren, W. A., Bertels, A., and Wall, D., 1968. Paleomagnetic stratigraphy and micropaleontology of three deep sea cores from the central North Atlantic Ocean: Earth Planet. Sci. Lett., v. 4, p. 118-130.

Poag, C. W., 1971. A reevaluation of the Gulf Coast PliocenePleistocene boundary: Gulf Coast Assoc. Geol. Soc. Trans., v. 21, p. 291-308.

Takayanagi, Y. and Saito, T., 1962. Planktonic foraminifera from the Nobori Formation, Shikoku, Japan. Tohoku Univ. Sci. Rept., Geol., v. 5, p. 67-106.

van Andel, T. H. and Veevers, J. J., 1967. Morphology and sediments of the Timor Sea: Australia Bur. Min. Res., Geol. Geophys. Bull., v. 83, p. 1-173. 


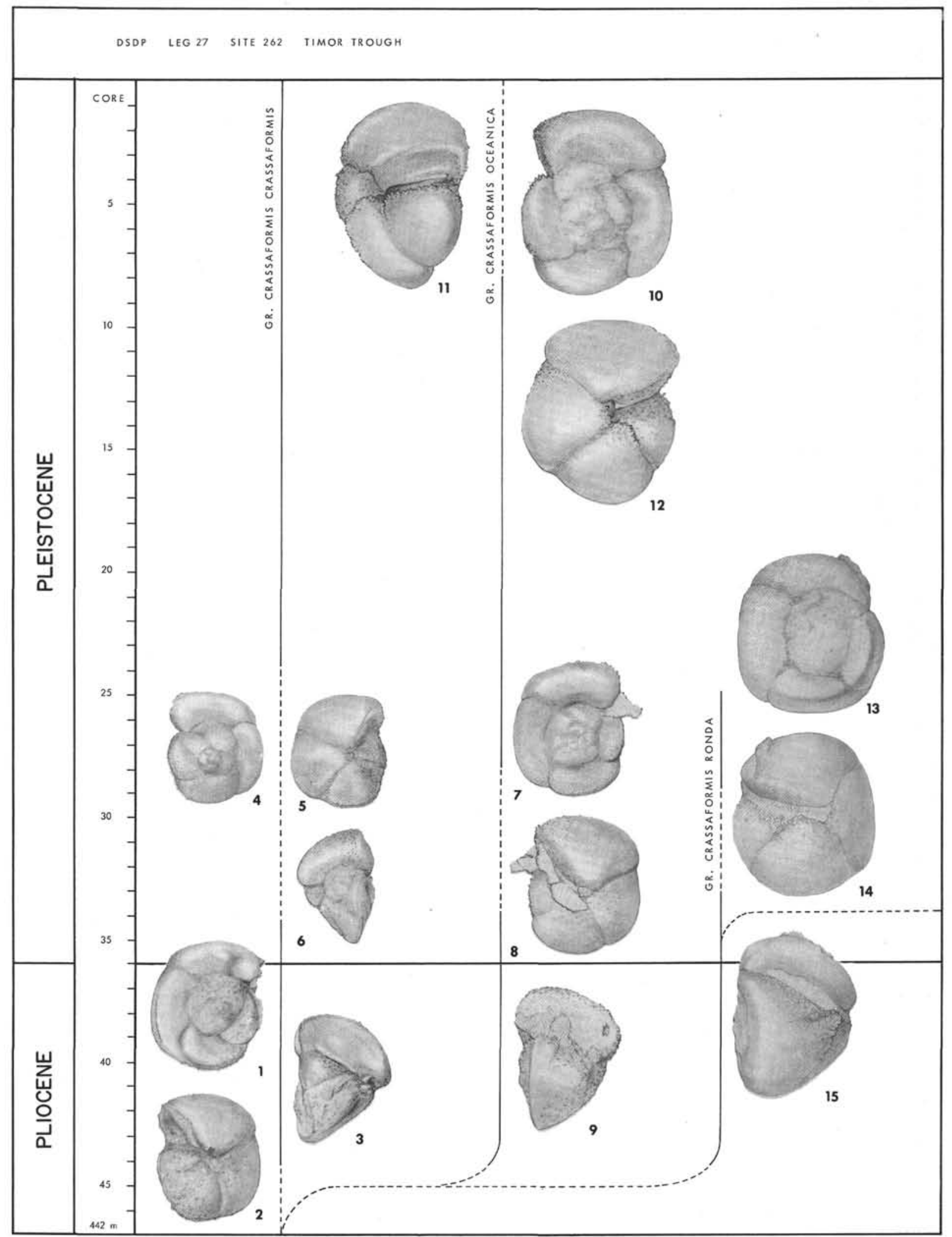

Figure 4. The evolution of the Globorotalia crassaformis group. 1-9: Globorotalia crassaformis crassaformis (Galloway and Wissler) (1-3: Sample 47, CC; 4-6: Sample 43-2, 104-106 cm). 7-12: Globorotalia crassaformis oceanica Cushman and Bermudez (7-9: Sample 44-3, 45-47 cm; 10-12: Sample 13, CC). 13-15: Globorotalia crassaformis ronda Blow (Sample 34, CC) 16-21: Globorotalia crassaformis hessi Bolli and Premoli Silva (16-18: Sample 23, CC; 19-21: Sample 2, CC). 22-24: Globorotalia crassaformis cf.viola Blow (Sample 22, CC). 25-27: Globorotalia aff. crotonensis Conato and Follador (Sample 17, CC). 


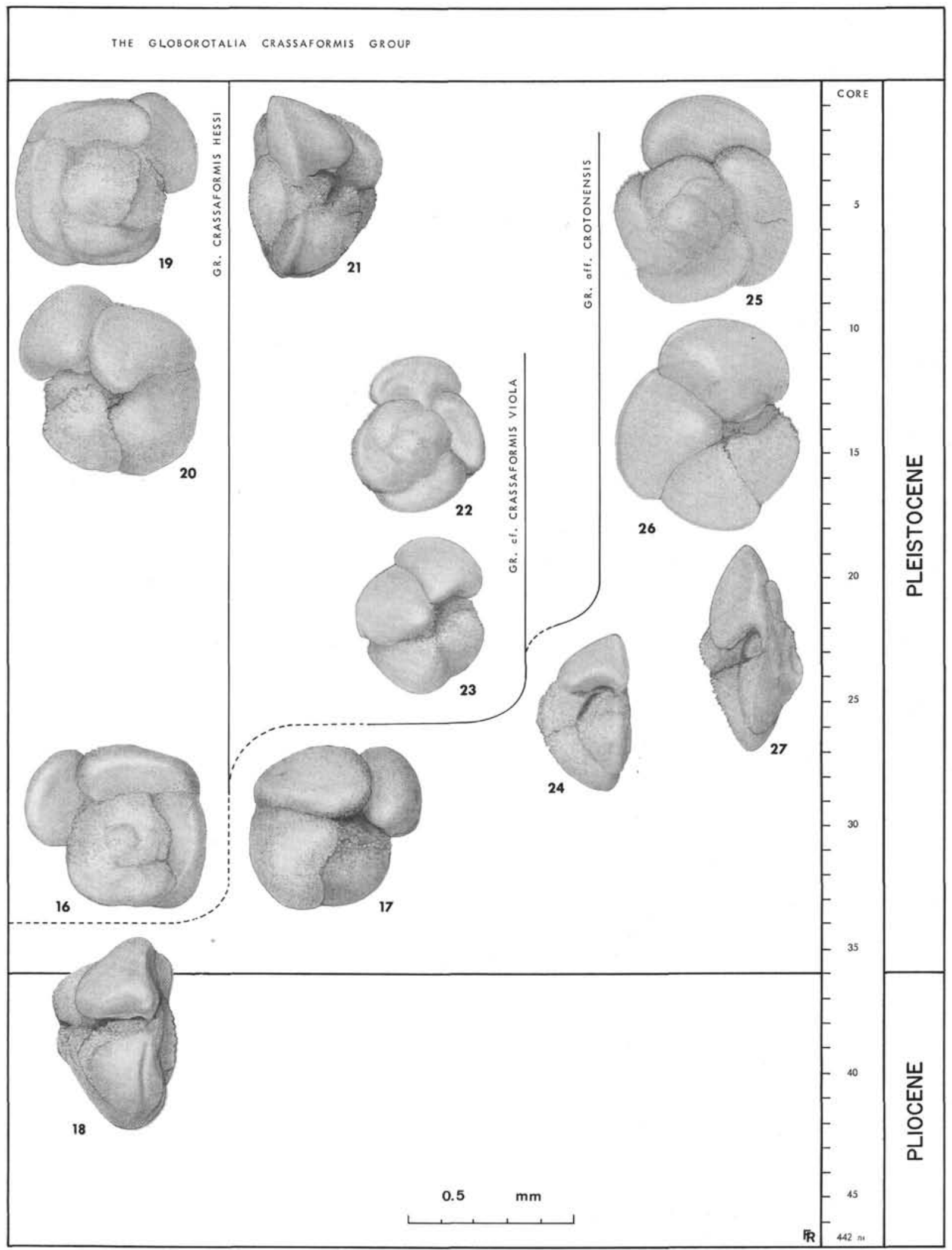

Figure 4. (Continued). 


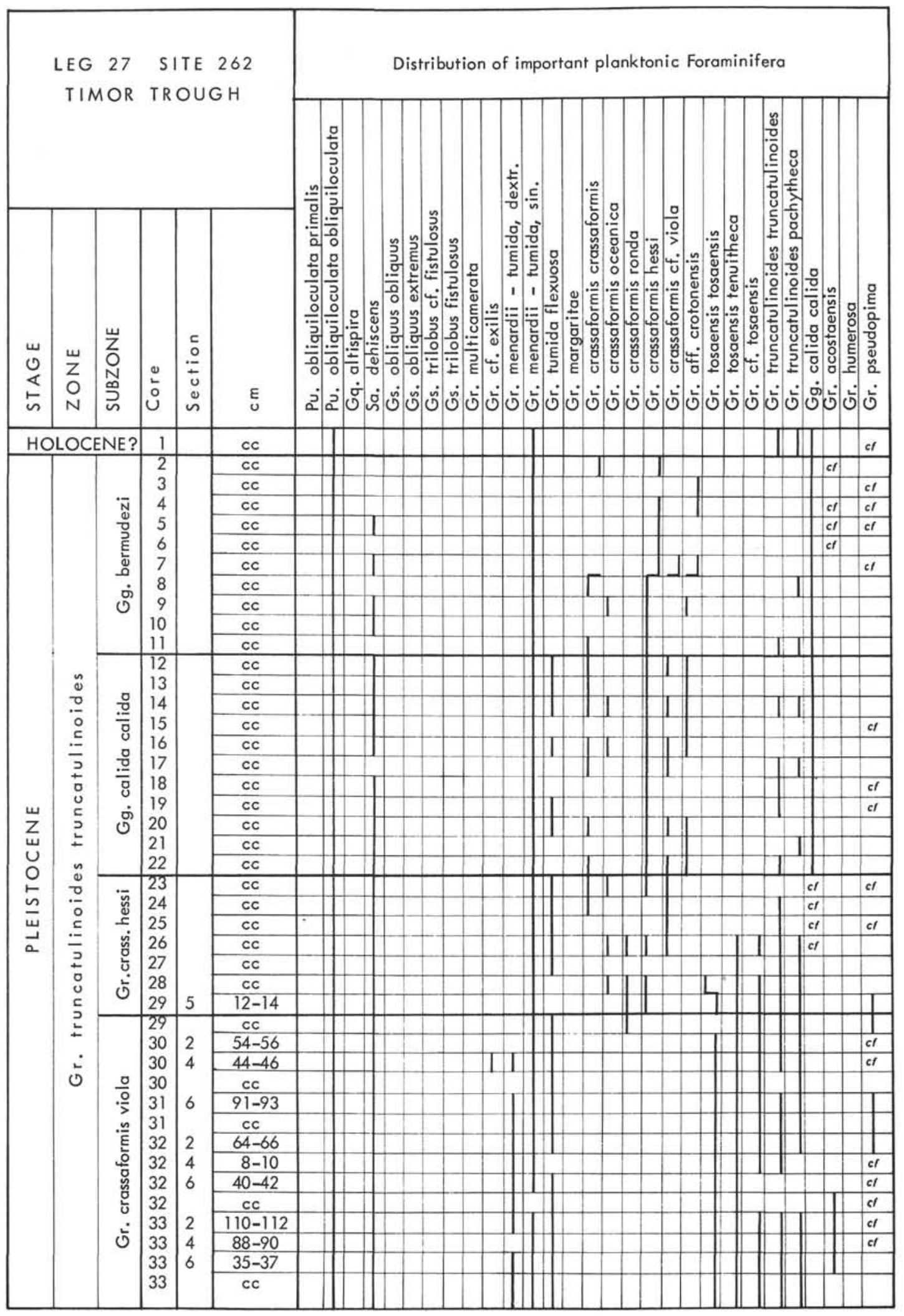

Figure 5.Distribution of selected planktonic foraminifera. The coiling direction of the Globorotalia crassaformis and G. tosaensis-truncatulinoides groups is shown as follows: line on left side of column indicates left coiling; right side, right coiling; and in the center, random coiling. Abbreviation: $c=$ contaminated; $c f=$ systematic determination is approximate. 


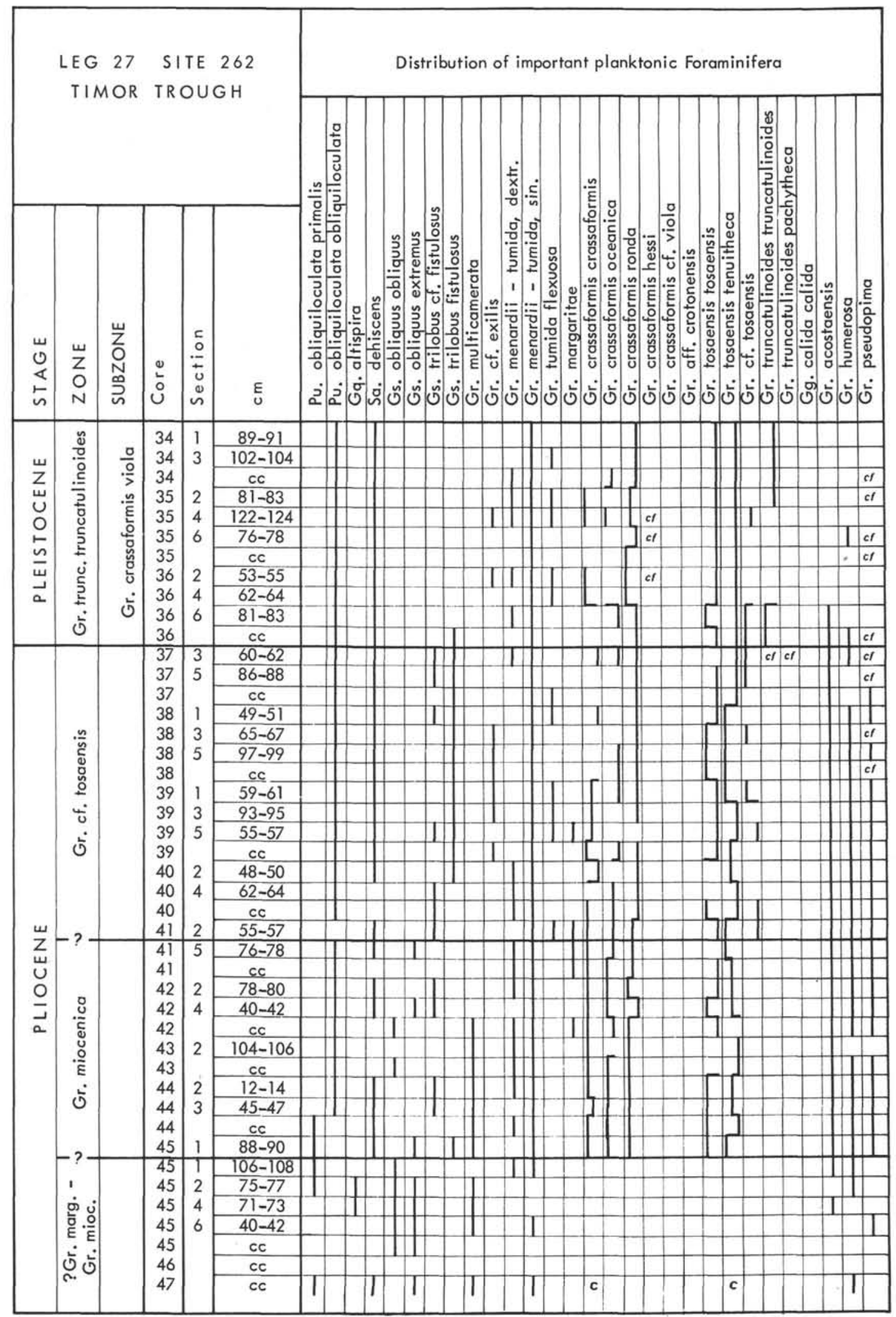

Figure 5. (Continued). 


\section{PLATE 1 \\ (Magnification: Figures 1-12, $\times 100$; Figures 13-18, $\times 75$.)}

Figures 1-3 Globorotalia sp., intermediate between G. crassaformis crassaformis and $G$. tosaensis tenuitheca. $G$. miocenica Zone; Pliocene.

1. Sample $44-2,12-14 \mathrm{~cm}$.

2. Sample $42-2,78-80 \mathrm{~cm}$.

3. Sample $44-3,45-47 \mathrm{~cm}$.

Figures 4-8 Globorotalia tosaensis tenuitheca Blow. G. cf. tosaensis Zone; late Pliocene.

6, 8. Sample 39-1, 59-61 cm.

5, 7. Sample $39-3,93-95 \mathrm{~cm}$.

4. Sample $39-5,55-57 \mathrm{~cm}$.

Figures 9-12 Globorotalia tosaensis tosaensis Takayanagi and Saito.

9. Sample 37, CC; G. cf. tosaensis Zone; late Pliocene.

10, 11. Sample 36-4, 62-64 cm; G. truncatulinoides truncatulinoides Zone, G. crassaformis viola Subzone, early Pleistocene.

12. Sample 36-2, 53-55 cm; G. truncatulinoides truncatulinoides Zone; G. crassaformis viola Subzone, early Pleistocene.

Figures 13-18 Globorotalia cf. tosaensis Takayanagi and Saito. G. truncatulinoides truncatulinoides Zone, $G$. crassaformis viola Subzone; early Pleistocene.

13, 14, 17. Sample 36, CC;

$15,16,18$. Sample $36-6,81-83 \mathrm{~cm}$. 

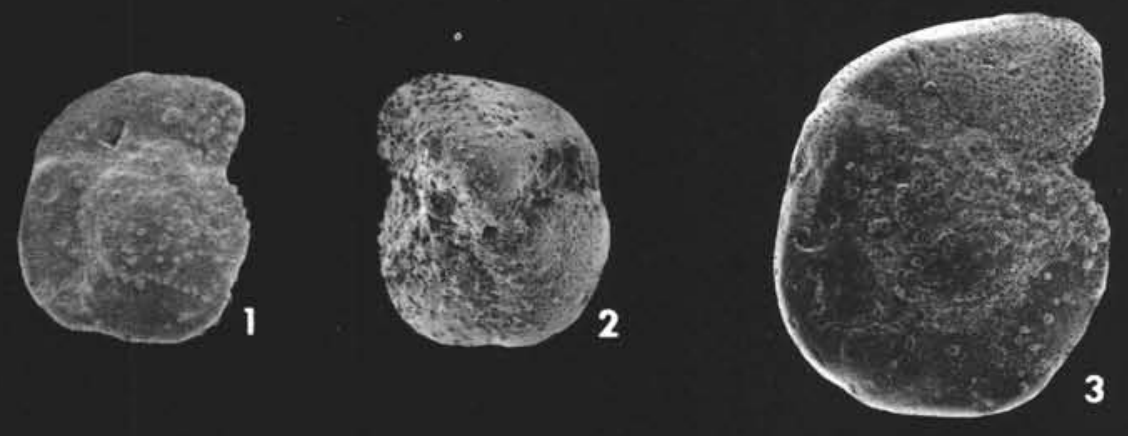

PLATE 1
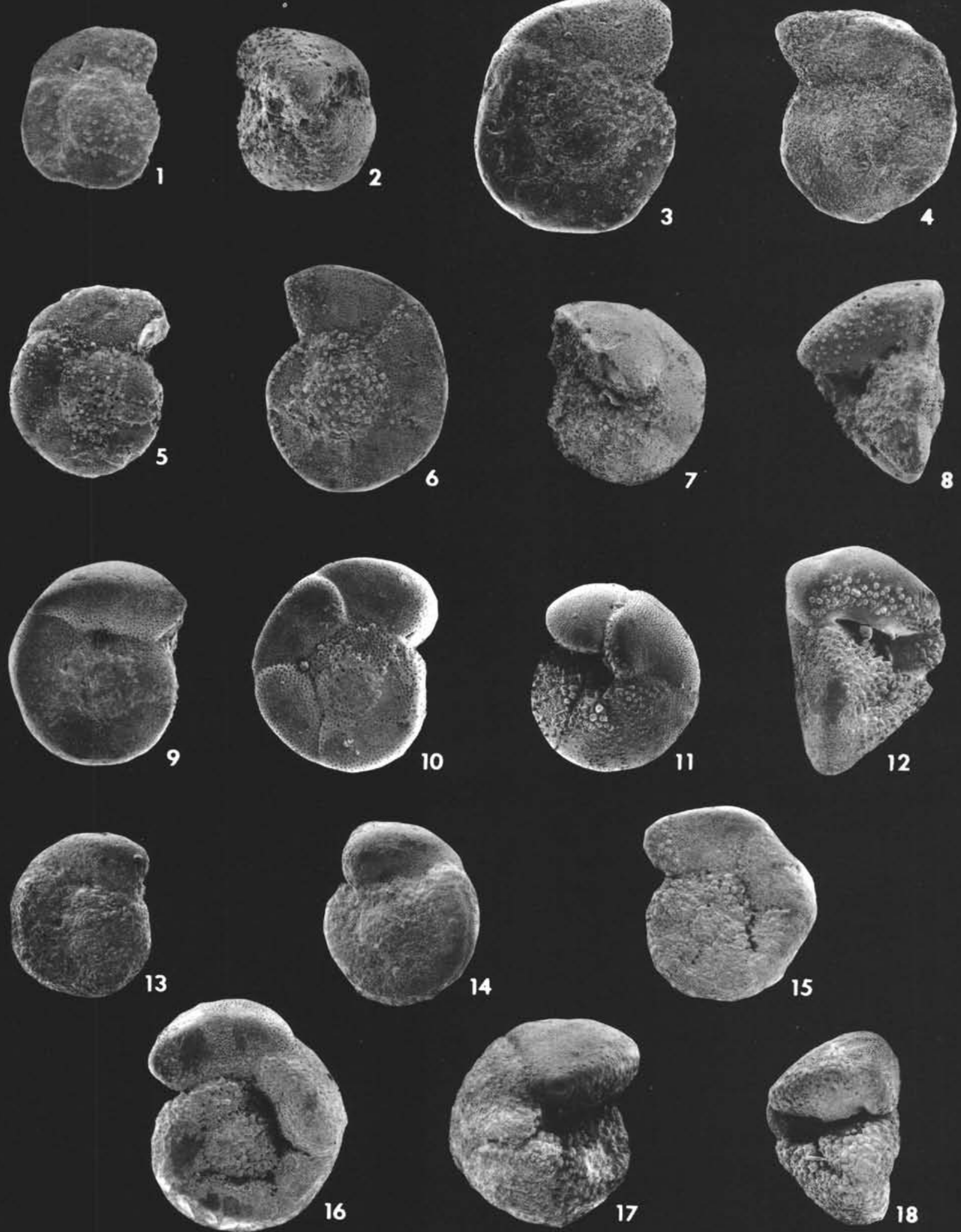
PLATE 2

(Magnification: $\times 75$ )

Figures 1-3, Globorotalia truncatulinoides truncatulinoides 7-10 (d'Orbigny). G. truncatulinoides truncatulinoides Zone.

1, 3. Sample 34, CC; G. crassaformis viola Subzone; early Pleistocene.

2. Sample 34-3, 102-104 cm; G. crassaformis viola Subzone, early Pleistocene.

7-10. Sample 14, CC; G. calida calida Subzone; late Pleistocene.

Figures 4-6, Globorotalia truncatulinoides pachytheca Blow. G. $11-13$ truncatulinoides truncatulinoides Zone.

4-6. Sample 33-6, 35-37 cm; G. crassaformis viola Subzone; early Pleistocene.

11,13. Sample 11, CC; G. bermudezi Subzone; late Pleistocene.

12. Sample 14, CC; G. calida calida Subzone; late Pleistocene. 
PLATE 2
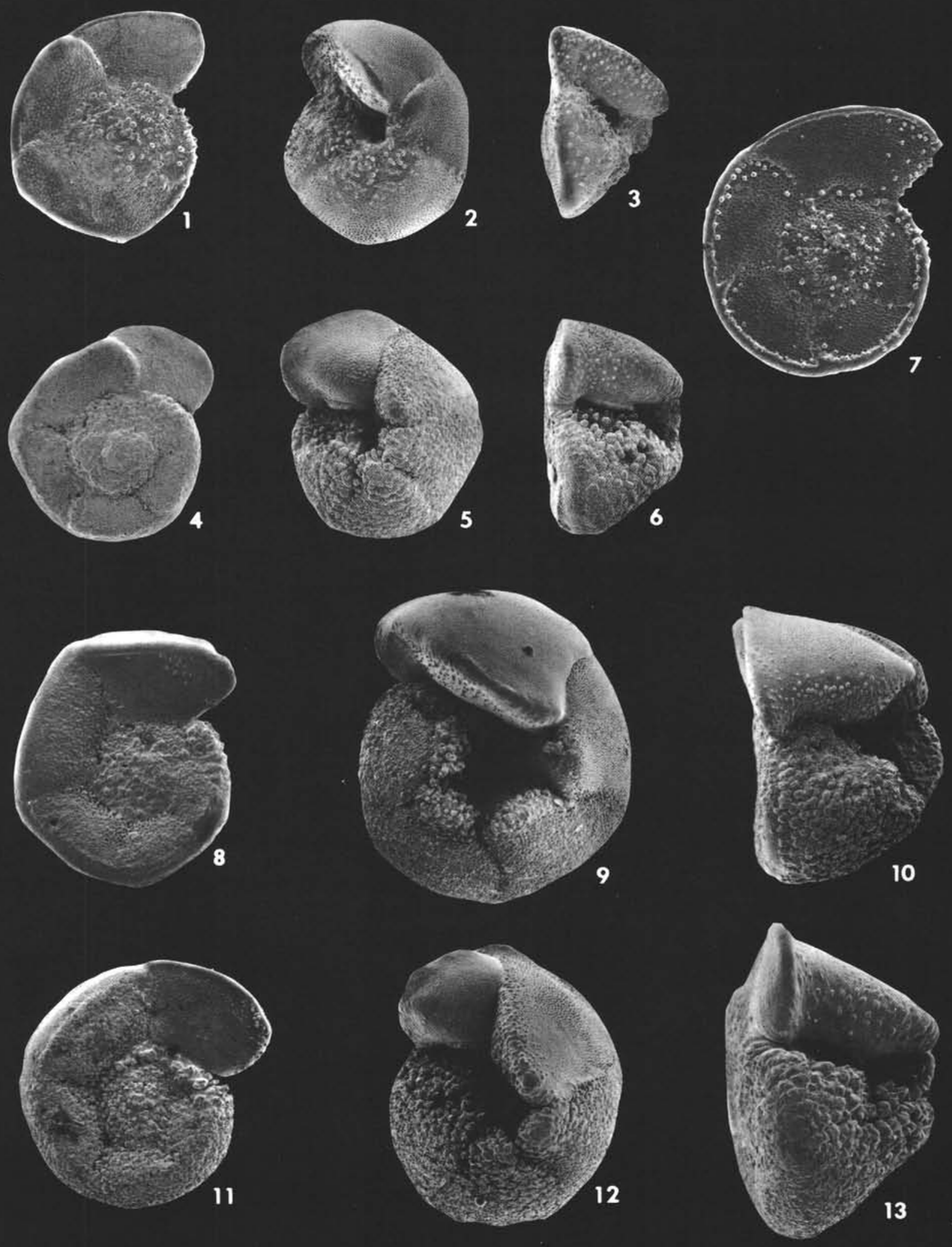
PLATE 3

(Magnification: Figures 1-9, 19-21 ×100; Figures 11-18, ×75.)

Figures 1-3 Globorotalia crassaformis crassaformis (Galloway and Wissler), small form of lower part of Site 262. G. miocenica Zone; Pliocene.

1, 3. Sample 41-5, 76-78 cm.

2. Sample 43, CC.

Figures 4, 5 Globorotalia crassaformis crassaformis (Galloway and Wissler), typical specimens. G. miocenica Zone; Pliocene.

4. Sample 43-2, 104-106 cm.

5. Sample $44-2,12-14 \mathrm{~cm}$.

Figure $6 \quad$ Globorotalia crassaformis oceanica Cushman and Bermudez. Sample 42-2, 78-80 cm; G. miocenica Zone; Pliocene.

Figures 7,8 Globorotalia crassaformis ronda Blow, transitional to $G$. crassaformis oceanica. G. miocenica Zone; Pliocene.

7. Sample 44-2, $12-14 \mathrm{~cm}$.

8. Sample $42-2,78-80 \mathrm{~cm}$.

Figures 9, 10 Globorotalia crassaformis ronda Blow, small, loosely coiled form of lower part of Site 262. G. miocenica Zone; Pliocene.

9. Sample 42, CC.

10. Sample $41-5,76-78 \mathrm{~cm}$.

Figures 11-18 Globorotalia crassaformis ronda Blow.

11-14. Sample 37-3, 60-62 cm; G. cf. tosaensis Zone; Pliocene.

15. Sample 36-6, $81-83 \mathrm{~cm} ; G$. truncatulinoides truncatulinoides Zone, G. crassaformis viola Subzone; early Pleistocene.

16-18. Sample 34, CC; G. truncatulinoides truncatulinoides Zone, G. crassaformis viola Subzone; early Pleistocene.

Figures 19-21 Globorotalia crassaformis oceanica Cushman and Bermudez. G. truncatulinoides truncatulinoides Zone.

19, 20. Sample 23, CC; G. crassaformis hessi Subzone; middle Pleistocene.

21. Sample 22, CC; G. calida calida Subzone; middle Pleistocene. 

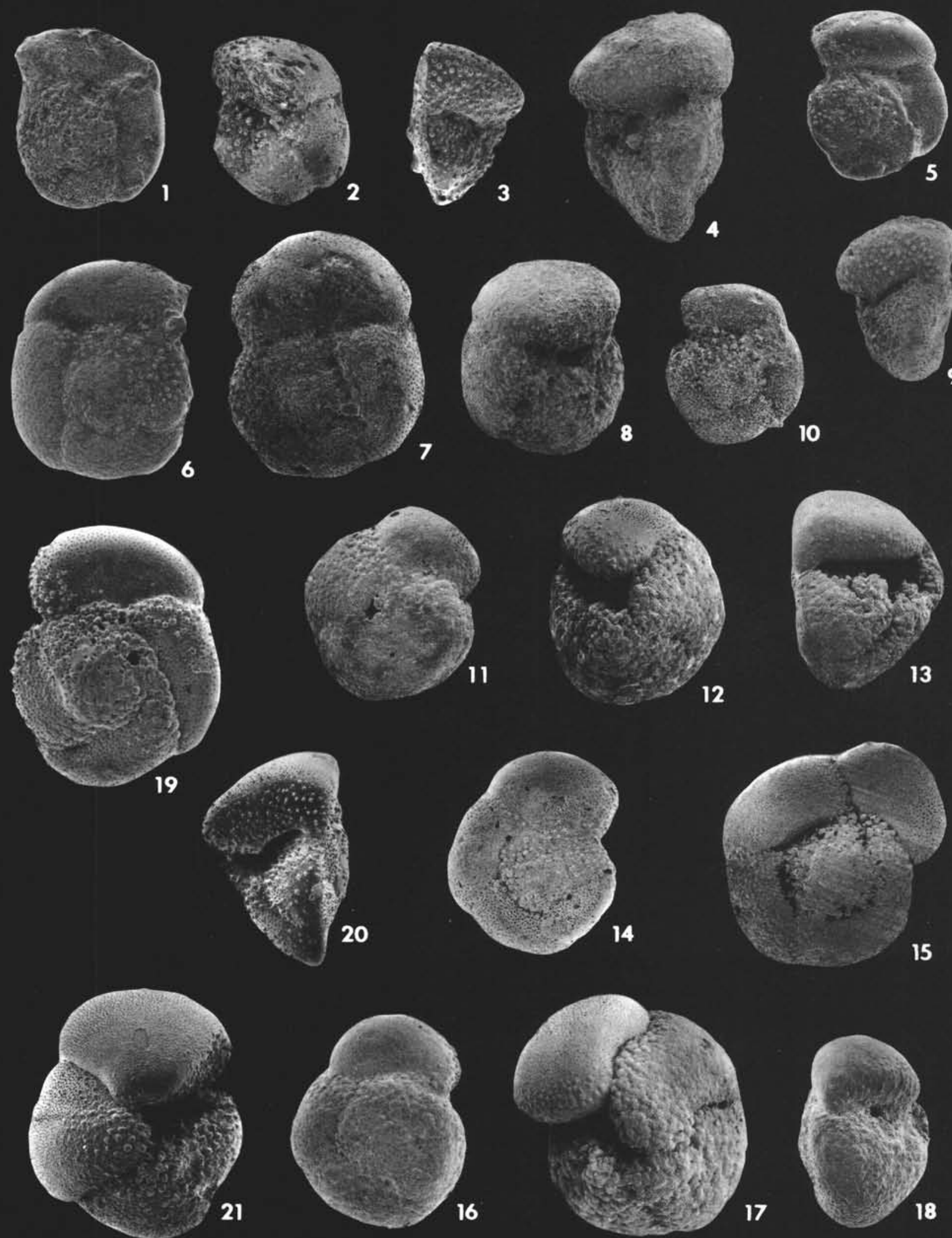
F. RÖGL

PLATE 4

(Magnification: All figures $\times 75$ )

Figures 1-7 Globorotalia sp., intermediate between $G$. crassaformis ronda and $G$. crassaformis hessi. $G$. truncatulinoides truncatulinoides Zone.

1-4. Sample 36-2, 53-55 cm; G. crassaformis viola Subzone; early Pleistocene.

5-7. Sample 23, CC; G. crassaformis hessi Subzone; middle Pleistocene.

Figures 8-19 Globorotalia crassaformis hessi Bolli and Premoli Silva. G. truncatulinoides truncatulinoides Zone.

8 , 10, 11. Sample 21, CC; G. calida calida Subzone; middle Pleistocene.

9. Sample 19, CC; G. calida calida Subzone; middle Pleistocene.

12-17. Sample 17, CC; G. calida calida Subzone; middle Pleistocene.

18. Sample 11, CC; G. bermudezi Subzone; late Pleistocene.

19. Sample 7, CC; right-coiling specimen; $G$. bermudezi Subzone; late Pleistocene. 
PLATE 4
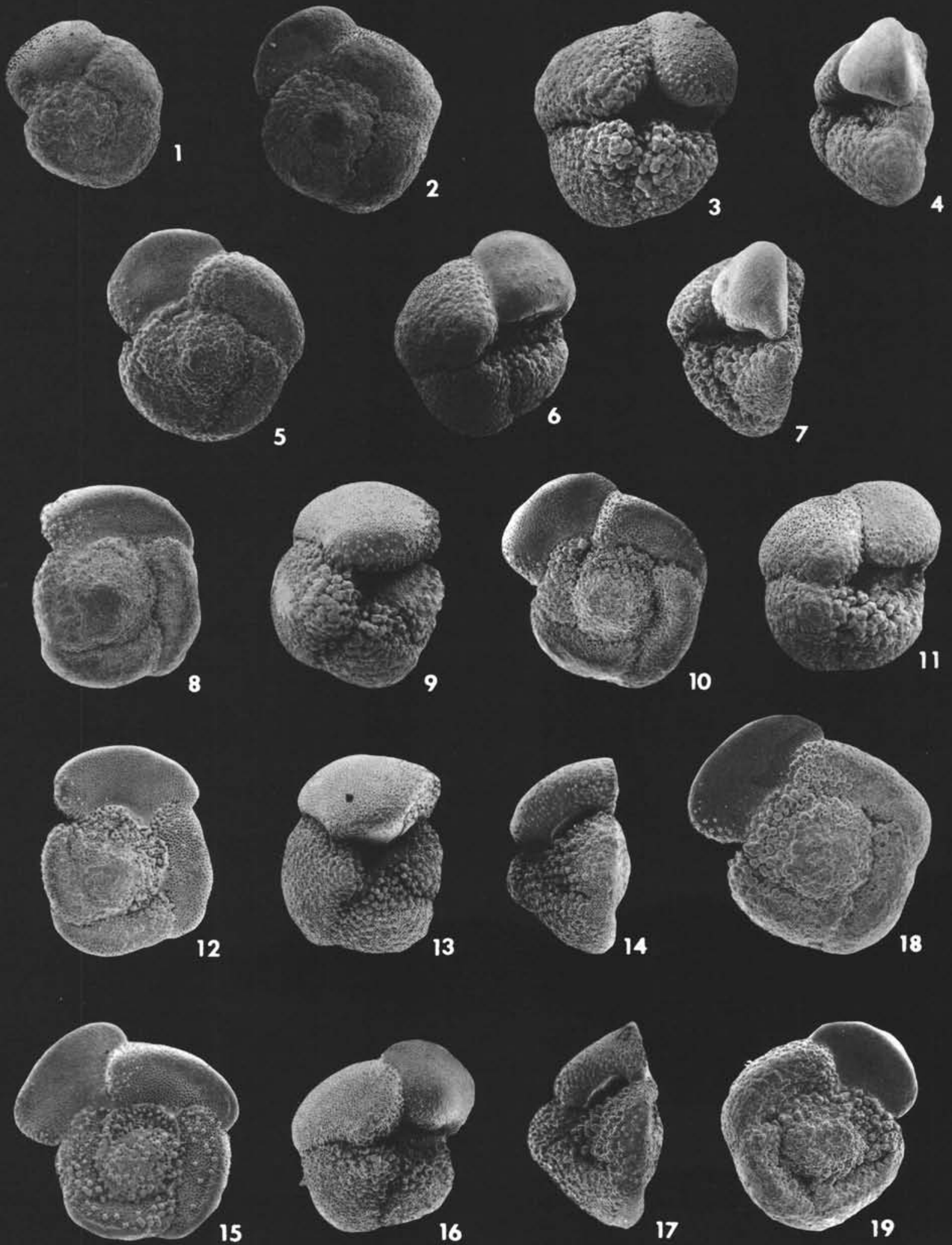
F. RÖGL

\section{PLATE 5}

(Magnification: All figures $\times 75$ )

Figures 1-9, Globorotalia crassaformis cf. viola Blow. $G$. 13-15 truncatulinoides truncatulinoides Zone. middle Pleistocene.

1-5. Sample 25, CC; G. crassaformis hessi Subzone.

6-9. Sample 24, CC; G. crassaformis hessi Subzone.

13-15. Sample 22, CC; G. calida calida Subzone.

Figures 10-12, Globorotalia aff. crotonensis Conato and Follador. $16-22$ G. truncatulinoides truncatulinoides Zone middle Pleistocene.

10-12, 19. Sample 22, CC; G. calida calida Subzone;

16-18. Sample 21, CC; G. calida calida Subzone. 20-22. Sample 7, CC; G. bermudezi Subzone. 


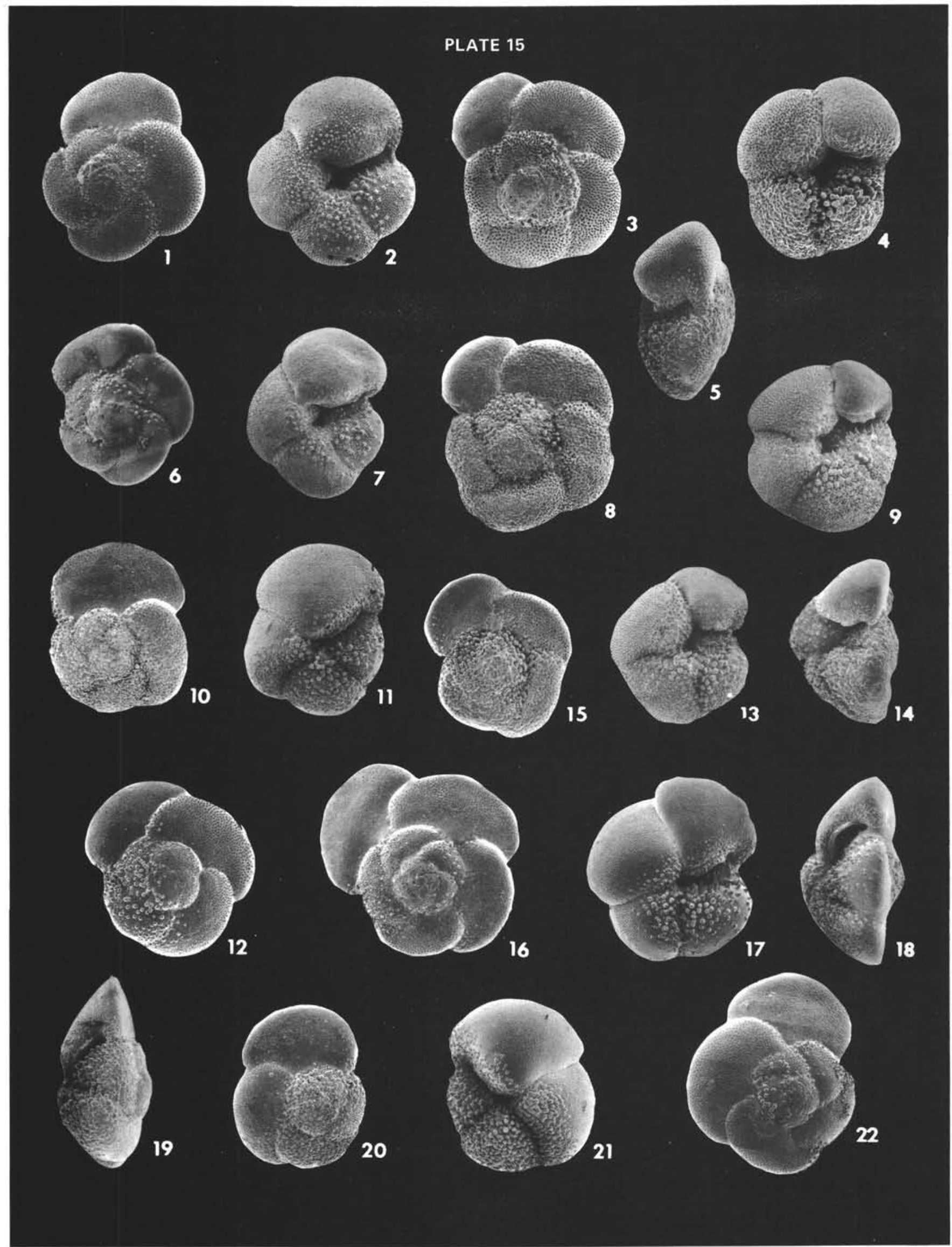

